\title{
Meta analysis: management control system, strategy, company performance
}

\author{
Desi Pujiati, Margianti, Misdiyono \\ Department of Accounting, Faculty of Economics, Gundarma University \\ *Corresponding author, e-mail: pujiati@staff.gunadarma.ac.id, \\ margianti@staff.gunadarma.ac.id,misdie@staff.gunadarma.ac.id
}

\begin{abstract}
This study aimed at determining and analyzing the meta analysis on journals review of the management control system, strategy and company performance theme. The management control system used lever's approach of control consisting of belief system, boundary system, diagnostic control system and interactive control system. The influence and impact of the management control system was resulted from previous research studies. This research used meta-analysis method. Meta-analysis is the study of a number of research results in similar problems. The unit of analysis in the study were written documents about the research of management control system in the form of journal articles and research reports taken purposively based on their compatibility with the research theme. Data analysis used was quantitative data analysis with percentage and qualitative data analysis for descriptive analysis result data on 25 research related to management control system. Findings of meta-analysis results based on research objectives, research variables used, population / sample of research, data collection techniques and analysis tools show that management control system lever's of control approach can contribute to the achievement of strategy and impact on business unit performance improvement.
\end{abstract}

Keywords: company performance, management control system, meta-analysis, strategy

Copyright $(2019$ APTIKOM - All rights reserved.

\section{Introduction}

Management control systems have different approaches used in research for strategy achievement. In the study [1] "Management control systems are categorized in many ways. For example, formal controls and informal controls proposed by [2], behavioral output and control markets, bureaucracy and control [3], administration and social control [3], actions and personnel control [4], [5] lever's control approach consisting of a belief system, a boundary system, a diagnostic control system and an interactive control system ". Lever's control system management approach is more dominantly used in research, therefore it needs to be analyzed by meta analysis.

The research model of management control system related to strategy there is still difference, where there is management control system become independent variable and dependent on strategy. The dominant model is the management control system that influences the strategy. This is in line with the management control system [6] stated in "The system used by management to control the activities of an organization is called its management control system. Management control is the process by which managers influence other members of the organization to implement the organization's strategic. An organization must be controlled, there must be a tool to ensure that organizational strategic organizational goals can be achieved.

The lever's control component of the management control system is used as an independent variable. The results showed that the effect of belief system, boundary system, diagnostic control system and interactive control system vary on strategy. It becomes interesting to make a meta-analysis of the components of the management control system. This is evident in the combination of effective management controls successfully tested on [7] studies in various strategic contexts through two related management control approaches as package and management control as a system. The analysis can be shown in several ways in which the corporate can effectively combine management control practices within a given strategic context. Furthermore, the analysis also shows that not all management control practices are found to be interconnected when examined simultaneously as a package. Second, based on the comparison of effective management control package.

The use of contingency components in the development of management control system research is widely used as a moderating variable. Contingency theory support has been put forward in response to a 
universal approach that argues that there is a way to design controls that apply to all corporate rules [8]. Contingency variables include, technology, firm size, organizational structure and environment are the variables used in initial contingency research on control systems. The contingency theory approach developed by [9] by designing the corporate's management and performance control system. The involvement of internal process elements, organizational structures and organizational culture in the application of management control systems is a research contribution from Bisbe and Otley [10].

One of the accounting researchers, [6] study result is the relationship between organizational factors and the establishment of management control systems using contingency theory. Effectiveness of the application of management control system supported one of them by contingency factor [10]. Cultural variables, work environment and compensation are involved in improving employee performance [11]. A research uses contingency variables, i.e environment, technology, organizational size and corporate strategy have an effect on determining management control system [12].

The development of research on management control system has been done by practitioners and academics all over the world. Various articles and research that seeks to explore the implementation of management control systems are well adopted in manufacturing and service companies. Empirical evidence of a management control management system that began in the 1980s. The relationship between the management control system of the lever's of control (LOC) approach to strategy has drawn attention in the management accounting literature [13-41]. It is demonstrated by the relationship between strategy and management control systems, and that a combination of contingency variables from management strategy and control systems impacts on performance outcomes. Based on the background disclosed above, the researchers are interested to examine the amount of contribution management control system lever's control approach in achieving the strategy and its impact on business unit performance.

\section{Literature Review \\ 2.1. System Belief}

The belief system proposed [42] is a formal communications senior manager formally and systematically strengthened to provide basic values, goals and direction for the organization. The main purpose of the belief system is to be inspired and as a guide to organizational search and discovery. A belief system communicated through basic values can be an inspiration and motivation for employees to search, explore, create and extend interesting points in appropriate behavior.

The belief system used through corporate culture teachings is communicated to every employee of the corporate. The belief system is generally broad and designed to attract different groups working in different departments [8].

Belief systems are the formal systems used by managers to be communicated and reinforced through the values of the basic objectives and direction of the organization. Belief systems are created and communicated through official documents, such as creeds, mission statements, and destination statements [42]. Mission statements, credo, and statement of purpose can be considered as part of the system when they are (1) formal, (2) information-based and (3) used by managers to maintain or change patterns within the organization of activities.

The reassessment stated [5] against the basic values for the corporate to be able to compete, the manager must use this information to ensure that internal operations are efficient and effective. Streamlining and realigning the environment of constant challenge and change creates a need for strong foundational values that can be given to organizational stability. Finally, the modern workforce has changed. Employees are educated with higher expectations of personal desires and the ability to contribute to the effort. If managers desire individual abilities to be transformed into good organizational output, each individual must understand the organization's goals and contribute to the corporate's goals. Management level efforts in empowering employees to be able to develop new ideas in order to achieve competitive advantage must be understood in corporate goals.

\subsection{Boundary Systems}

The boundary system is a formal system used by the management level in the determination of explicit boundaries and rules that must be obeyed. The boundary system is usually declared in negative terms or as a minimum standard. The boundary system is created through ethical codes, strategic planning systems, and operational directives available to business managers, risk analysis to avoid from the influence of boundary systems [42]. This is supported by the research of [15] that the boundary system is created and communicated through code written and rules as a reference tendency to overcome the diversity of companies and for the growing complexity of Telecommunications companies in the UK. 
The boundary system is based on the principle that employee empowerment, easier and more effective through the establishment of rules to regulate employee behavior that is in the corporate's best interests. The limiting system works on the premise that empowered employees should not be given the freedom to do whatever they want. Employees should be focused on their efforts on areas that are in the corporate's interest, in terms of profitability, productivity and efficiency [8].

Rules as written guidelines containing all types of instructions and controls, for example: job instructions, job divisions, standard operating procedures and guides [6]. Rules in the control system are:

- Physical control,

- Manual, written rules such as guidelines.

- Security system, this system is made accurately and avoid cheating with security being

- made on information processing systems.

- Task control system, the system is created to ensure that the task done can be effective and

- efficient.

According to [4], the code of ethics is a statement of values adopted by the corporate, its employees and top management establish the official attitude of top management regarding the behavior expected by the corporate. Companies are looking for new employees who have a good ethical ground because they realize that someone who is ethical is more likely to succeed. The corporate's challenges can be overcome by strengthening the ethical cultural foundation, so that the corporate gains the trust and loyalty of its employees and stakeholders. Code of ethics communicated by the corporate should be able to train employees to behave according to corporate goals not only used as manuals. This has an impact on reducing financial, legal and reputation risks and improving organizational performance.

\subsection{Diagnostic Control System}

Diagnostic Control Systems are formal feedbacks used to monitor organizational outcomes and irregularities that do not conform to established standards of performance [5]. The diagnostic control system applied to the business plan and budget is the feedback system used to detect deviations from the intended purpose.

Quantitative data, statistical analysis and variance analysis are used in diagnostic control systems that have potential differences. Diagnostic systems can be useful for detecting problems, but they can also lead employees and managers to behave unethically to meet established goals [8]. Employee benefits are often based on how well the performance results are achieved. Diagnostic system works well if the achievement of results in accordance with the expected target.

The routine tasks of managers can be mitigated by the presence of a diagnostic control system to monitor employees so that employees work diligently as usual to meet established goals. However, when goals are realistic, empowered employees may sometimes even use their creativity to manipulate factors under their control to work according to the targets the manager wants to achieve. Such manipulation in the short term may be a very positive effect, but it can have an impact on long-term problems for the company.

The routine tasks of managers can be mitigated by the presence of a diagnostic control system to monitor employees so that employees work diligently as usual to meet established goals. However, when goals are realistic, empowered employees may sometimes even use their creativity to manipulate factors under their control to work according to the targets the manager wants to achieve. Such manipulation in the short term may be a very positive effect, but it can have an impact on long-term problems for the corporate.

Diagnostic control systems are defined as systems that serve as the backbone of traditional management controls, designed to ensure the achievement of defined goals. In organizations of any size, complexity of operations and the number of decisions required in subordinate activities for decision making. At the same time, senior managers need to ensure that decisions are made by subordinates in line with organizational goals. [5] outlines three features of a diagnostic control system namely; the ability to measure the output of a process, the existence of predetermined standards against which actual results can be compared and the ability to correct deviations from the standard.

\subsection{Interactive Control System}

An interactive control system (Interactive Control Systems) is a formal system used by managers to organize and personally engage in subordinate activities [42]. The purpose of creating an interactive control system is to focus on the attention and dialogue of strength and learning throughout the organization.

Strategic uncertainty is the concern of management control systems [42]. Once business basics are in terms of mission, strategic, diagnostic control systems and related incentives, managers focus on their personal involvement in highly interactive control systems. An interactive control system has four characteristics: 1) information generated by the system is an important agenda and resolved repeatedly by

APTIKOM J. CSIT Vol. 4, No. 3, 2019: 96 - 104 
the management level; 2) an interactive control system demands frequent and regular attention from the operations manager at all levels of the organization; 3) the data generated by the system is interpreted and discussed in meetings at the management level and 4) the system becomes a challenge for continuous discussion based on data, assumptions, and actions.

The interactive use of the management control system in research [18] generated a positive influence on the corporate's capability and impacted the corporate's performance. The focus of this research is the attention and mechanism of dialogue throughout the organization. This can lead to the development of new ideas and initiatives and guidance on the emergence of a bottom-up strategy by focusing on strategic uncertainty. Management control systems are used interactively, 1) the resulting information is a recurring agenda and is important for top managers; 2) frequent and regular attention is fostered throughout the organization; 3) Data is discussed and interpreted between hierarchical member organizations and 4) persistent challenges and the debate takes place about data, assumptions and action plans.

\subsection{Management Control Systems and Competitive Strategies}

The competing strategy in the research of the management control system is conceptualized as Porter's approach (1980) which consists of low cost strategy and differentiation strategy. Support of previous research on management control system with competitive strategy $[14,43,28]$ The competitive advantages of business units must be developed to implement competitive strategies.

The belief system, the boundary system, the diagnostic control system and the interactive control system work to implement the planned strategy and formulated emerging strategies as presented in Figure 1. below.

Strategy as "perpective" Strategy as "Position"

Belief Systems Boundary Systems

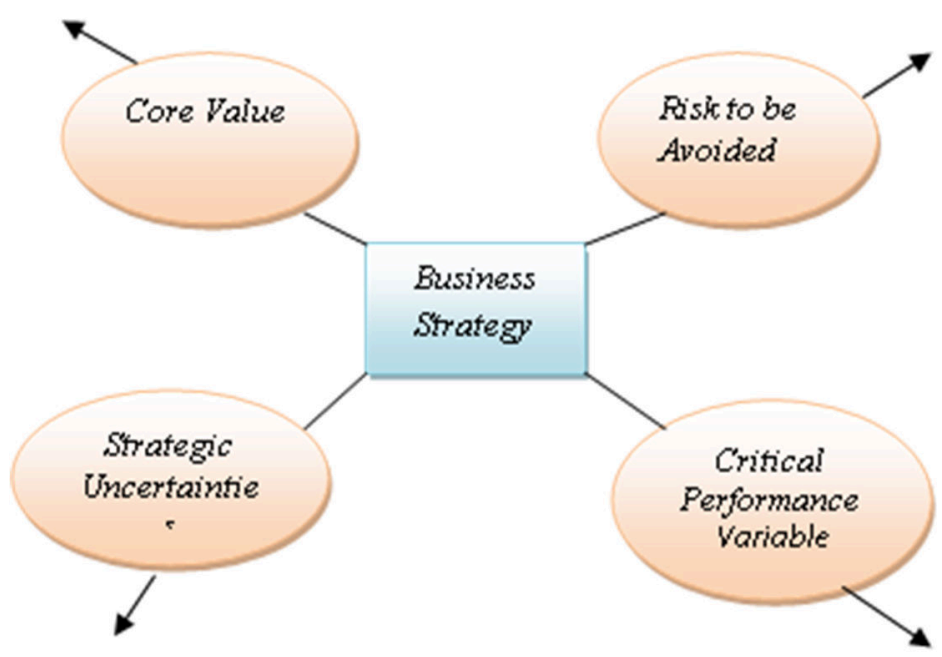

Interactive Control Systems Diagnostic Control System Strategy as "Patterns in Action" Strategy as "Plan

Figure 1. Lever's of Control

Source: Simon (1995)

\subsection{Corporate Performance}

Corporate performance is an indicator of the success of a corporate that is measured according to the period of time specified. Achievement of this performance can be said as the value of any activity that has been planned, implemented and controlled to be identified whether the strategy made according to corporate goals.

Corporate performance is a difficult concept in its measurement [13], because as a construct is multidimensional to measure the impact of corporate strategy. Corporate performance consists of several components, such as financial performance, marketing performance, performance management, employee performance, and others. The impact of management control systems on managerial performance is on 
Otley's [13] research managerial perspective: objectives, strategic and plants, targets, rewards, feedback strategies can be implemented.

The performance measurement system proposed by Anthony \& Govindarajan [16] is a corporate goal can be achieved by means of a strategy can be achieved. This measure of performance can be seen as an important factor in both short and long term success. The use of belief systems and administrative controls on the use of corporate-level strategies resulted in higher ROI and sales turnover (ROS) levels in [42]. The study was conducted in telecommunication industry of lower and middle level managerial level of analysis.

\section{Research Methodology}

This research uses Meta Analysis design. Meta analysis can simply be interpreted as an analysis of the analysis. As a study, meta-analysis is a review of a number of research results in similar problems. Instruments in this study using Human Instrument. After the focus of the research becomes clear, it will develop a simple research instrument, which is expected to complement the data and compare back data that has been found previously. Data collection techniques will use documentation techniques.

Population in this research is all written document about research of management control system approach of lever's of control. The written documents are: books, journal articles, and research reports. The sample was taken using Purposive Sampling technique. This is because the data or information to be obtained from the sample is determined based on its compatibility with the theme of this research. The data analysis used is quantitative data analysis with percentage and qualitative data analysis for the data of result of narrative study to the researches encountered.

\section{Result and Discusion}

\subsection{Results Meta Analysis}

The research on management control system of lever's control approach obtained is 25 researches. Similar research is obtained from various sources, namely: articles (research results) in research journals and research reports. In general, the data obtained by downloading from the internet. The research used as meta-analysis is as the Table 1 below

Table 1. List of journal analyzed using metaanalysis

\begin{tabular}{llll}
\hline No & Researchers & Publication Year & Reference Number \\
\hline 1. & Simon & 1990 & {$[14]$} \\
2. & Simon & 1991 & {$[42]$} \\
3. & Simon & 1994 & {$[44]$} \\
4. & Langfield-Smith & 1997 & {$[1]$} \\
5. & Marginson & 2002 & {$[15]$} \\
6. & Bisbe and Otley & 2004 & {$[10]$} \\
7. & Henri & 2005 & {$[18]$} \\
8. & Widener & 2007 & {$[19]$} \\
9. & Peljhan & 2007 & {$[20]$} \\
10. & Peljhan & 2008 & {$[21]$} \\
11. & Caglio and Zoni & 2010 & {$[10]$} \\
12. & Agbejule & 2011 & {$[24]$} \\
13. & Patrick et al & 2011 & {$[26]$} \\
14. & Ahsina & 2012 & {$[27]$} \\
15. & Ismail et al & 2012 & {$[29]$} \\
16. & Lee and Widener & 2013 & {$[36]$} \\
17. & Arachchilage and Smith & 2013 & {$[28]$} \\
18. & Ismail & 2013 & {$[31]$} \\
19. & Ismail & 2014 & {$[32]$} \\
20. & Mohamed et al & 2014 & {$[38]$} \\
21. & Eldridge, Iwaarden, Van der Wiele & 2014 & {$[39]$} \\
& and Williams & & \\
22. & Utary & 2014 & {$[40]$} \\
23. & Ismail and Bangun & 2015 & {$[33]$} \\
24. & Bedford, Malmi and Sandelin & 2016 & {$[7]$} \\
25. & Nisiyama & 2016 & {$[41]$} \\
\hline Source: Processed researchers (2018) & &
\end{tabular}

APTIKOM J. CSIT Vol. 4, No. 3, 2019: $96-104$ 
The meta Analysis based on research objectives, research variables used, population / sample of research, data collection techniques and analysis tools.

\subsection{Meta Analysis Based on Research Objectives}

The objectives of the management control system of the lever's control approach are to examine the influence of the strategy, the influence on the strategy and the impact on business unit performance, to describe the management control system. Based on the study of 25 studies, it can be generated data as follows in Table 2 below.

Table 2. Objectives in research

\begin{tabular}{llcc}
\hline No & \multicolumn{1}{c}{ Objectives in Research } & Frequency & $(\%)$ \\
\hline 1. & Examine influence on strategy & 4 & $16 \%$ \\
2. & $\begin{array}{l}\text { Examine the impact on strategy and impact on } \\
\text { business unit performance }\end{array}$ & 11 & $44 \%$ \\
& $\begin{array}{l}\text { Describe } \\
\text { amount }\end{array}$ & 10 & $40 \%$ \\
& 25 & $100 \%$ \\
\hline Sourcer
\end{tabular}

\subsection{Meta Analysis Based on Research Variables}

The research variables used in the research of management control system of lever's control approach obtained belief system, boundary system, diagnostic control system, interactive control system. Similar studies exist that use only belief systems, interactive control systems only, diagnostic control systems and interactive control systems. Based on the study of 25 studies, it can be generated data as follows in Table 3. below.

Table 3. Research variables

\begin{tabular}{|c|c|c|c|}
\hline No & Variabel Penelitian & Frequency & $(\%)$ \\
\hline 1. & Belief System & 1 & $4 \%$ \\
\hline 2. & Interactive Control System & 5 & $20 \%$ \\
\hline 3. & $\begin{array}{l}\text { Diagnostic Control System and Interactive } \\
\text { Control System }\end{array}$ & 10 & $40 \%$ \\
\hline 4. & $\begin{array}{l}\text { Belief System, Boundary System, Diagnostic } \\
\text { Control System and Interactive Control System } \\
\text { amount }\end{array}$ & 25 & $36 \%$ \\
\hline
\end{tabular}

\subsection{Meta Analysis by Population/Sample Research}

The population/sample used in the research of the management control system of the lever's control approach is the level of management of the three levels of the firm. The management level level consists of top management, middle level management and lower level management. Based on a study of 25 researches on the management control system of the lever's control approach, the people who are made into groups / samples are grouped with top management only, middle management only and high and middle level management that can be seen in Table 4 below.

Table 4. Population/sample research

\begin{tabular}{llcc}
\hline No & \multicolumn{1}{c}{ Population / Sample Research } & Frequency & $\mathbf{( \% )}$ \\
\hline 1. & Top management & 4 & $16 \%$ \\
2. & Middle level management & 10 & $40 \%$ \\
3. & Top level and middle level management & 11 & $44 \%$ \\
& amount & 25 & $100 \%$ \\
\hline Source: Proced ros
\end{tabular}

Source: Processed researchers (2018)

\subsection{Meta Analysis Based Data Collection Techniques}

Methods /techniques of data collection used in research management control system lever's of control approach consists of: observation methods, questionnaires, and interviews. Based on the study of 
25 studies on management control system lever's of control approach, the method / technique of data collection used can be seen in Table 5 below.

Table 5. Data collection techniques

\begin{tabular}{llcc}
\hline No & Data Collection Techniques & Frequency & $\mathbf{( \% )}$ \\
\hline 1. & Observation & 3 & $12 \%$ \\
2. & Questionnaire & 15 & $60 \%$ \\
3. & Interview & 7 & $28 \%$ \\
& amount & 25 & $100 \%$ \\
\hline Source: & Processed researchers $(2018)$ & &
\end{tabular}

Source: Processed researchers $(2018)$

\subsection{Meta Analysis Based on Data Analysis}

The data analysis used in the research of management control system of lever's control approach consists of; regression, qualitative analysis and quantitative analysis. Based on a study of 25 studies on management control systems lever's control approach, the data analysis used can be seen in Table 6 below.

Table 6. Data analysis

\begin{tabular}{llcc}
\hline No & \multicolumn{1}{c}{ Data Analysis } & Frequency & $(\%)$ \\
\hline 1. & Qualitative Descriptive & 10 & $40 \%$ \\
2. & Descriptive Quantitative (regression) & 5 & $20 \%$ \\
3. & Descriptive Quantitative (SEM) & 10 & $40 \%$ \\
& amount & 25 & $100 \%$ \\
\hline Sourc:
\end{tabular}

Source: Processed researchers (2018)

\section{Discussion}

Research on management control system based on the research objectives obtained the largest ratio of research on the impact on strategy and impact on performance. This proves that the management control system can be used as a tool to influence corporate members in achieving corporate strategy. The achievement of corporate strategy gained from the implementation of management control system has an impact on business unit performance. The result of the proof can be used as a reference for the researcher in the field of management control system to develop the research with the influence model of control system to the strategy and impact on the performance. The second largest ratio of meta-analysis has a research objective that describes a management control system. This can prove that the research describing is still interesting to be studied because the management control system depends on the condition of the corporate in achieving the strategy and business unit performance.

Research on management control system based on research variables obtained the largest ratio of research using variable control system diagnostic and interactive control system. This proves that the diagnostic control system is very helpful to the level of management in influencing the members of the corporate in monitoring the results, rewards and sanctions. An interactive control system can also encourage corporate members to create ideas through discussion and communication. The second fastest ratio of metaanalysis using variables consisting of belief systems, boundary systems, diagnostic control systems and interactive control systems is still interestingly researched. This proves that the management control system of the lever's control (Simon, 1995) approach is still interesting to be examined in the achievement of strategy and impact on business unit performance.

Research on management control system based on population / research sample obtained the largest ratio of research using population / sample on top management and middle level management. This proves that the respondents used in this research are addressed to people who have control in managing the corporate, involved in formulating and implementing corporate strategy in order to improve business unit performance. The second largest population / sample ratios of this study are in the middle management level. This proves that the management control system applied requires the role of middle level management in communicating the target achievement strategy that has been formulated by top management level to lower level management.

Research on management control system based on data collection technique obtained the largest ratio using questionnaire. This proves that the corporate's management control system requires the perception of management level to the indicator used. Management level perceptions can describe indicators of management control systems assist in achieving strategy and impacting business unit

APTIKOM J. CSIT Vol. 4, No. 3, 2019: $96-104$ 
performance. The second largest ratio of data collection techniques is by interview. It can also be used as a reference that interview results are still interesting to use and more reflect the corporate's real conditions in achieving strategy and improve business unit performance.

Research on management control system based on data analysis obtained the largest ratio using quantitative descriptive using both regression and Structural Equation Modeling (SEM). This proves that the research management control system that has the purpose of knowing the influence on the strategy and impact on the performance of the business unit of course using quantitative descriptive. Descriptive quantitative is in accordance with the results of previous meta-analysis that has the purpose of knowing the effect on strategy and its impact on business unit performance, population / sample using management level and data collected through questionnaires. The result of the data obtained is processed by means of quantitative descriptive analysis using both regression and Structural Equation Modeling.

\section{Conclusion}

Based on the results of research and discussion of research, it can be concluded that the field of management control system research has an effect on competitive strategy and impact on business unit performance. The components of the management control system are often used in the diagnostic control system and the interactive control system in improving the competitive strategy. Population and sample of research on management control system exist at all levels of management level of upper, middle and lower management. Data collection techniques in exploring the perceptions of management system control components by using questionnaires. In analyzing the data on the research of management control system with qualitative descriptive and quantitative descriptive (SEM). The upcoming research suggestion in the meta-analysis of management control systems adds meta-hypothesis results.

\section{References}

[1] Langfield-Smith,K. Management Control Systems and Strategy:A Critical Review. Accounting, Management and Society. 1997. Vol.22(2): 207-232.

[2] Anthony, Dearden, and Bedford. 1989. Management Control System. Edisi 6. Jakarta: Bina Aksara.

[3] Outchi, W.G. A Conceptual Framework For Design of Organizational Control Mechanisms. Management Science . 1979. Vol.25(9): 833-848.

[4] Merchant, K. A \& Van der Stede,W. A. Management Control System Performance, Evaluation and Incentive. Edisi 3. Prentice Hall. 2007. British Library Cataloguing-in-Publication. 118-126.

[5] Simon. Levers of control. Harvard University Press. Boston. 1995: 116-157.

[6] Anthony, R. N \& Govindarajan, V. Management Control System. book 1. Jakarta: Salemba Empat. 2015: 3-119.

[7] Bedford, D. S, Malmi, T and Sandelin, M. Management Control Effectiveness and Strategy: An Empirical Analysis of Packages and Systems. Accounting, Organizations and Society. 2016. Vol.5(1): 12-28.

[8] ICFAI. Principles of Management Control Systems. Center for Management Research. 2006. ISBN 81-7881995-3. 20, 281-282.

[9] Fisher, J. Contingency-Based Research: Management Control System categorization by Level of Complexity. Journal Accounting of Literature. 1995.Vol.14: 24-48.

[10] Bisbea, J \& Otley,D. The Effects of The Interactive Use of Management Control Systems on Product Innovation. Journal Accounting Organizations and Society. 2004. Vol.29: 709-737.

[11] Carenys, J. Management Control Systems: A Historical Perspective. International Journal of Economy, Management and Social Sciences. 2012. Vol.1(1): 1-18.

[12] Chenhall, H. Management Control Systems Design Within its Organizational Context: Findings from Contingency-Based Research and Directions for The Future. Journal Accounting, Organizations and Society. 2003: Vol.28: 127-168.

[13] Otley, D.Performance management: a framework for management control systems research. Journal Management Accounting Research. 1999. Vol.10: 363-382.

[14] Simons, R. The Role of Management Control Systems in Creating Competitive Advantage New Perpectives. Journal Accounting Organization and Society. 1990. Vol.15(1): 127-143.

[15] Marginson, D.E.W. Management Control Systems and Their Effect on Strategy Formation at MidlleManagement levels: Evidence of A.UK Organization. Strategic Management Jounal. 2002: Vol.23: 1019-1031.

[16] Malga, A. S. Effect of Management Control System on Manufacturing Performance: A Path Analytical Model. Journal of Applied Management Accounting Research. 2004. Vol.2(1): 13-28.

[17] Kober, R, Juliana NGB, Paul, B.J. The Interrelationship Between Management Control Mechanisms and Strategy. Management Accounting Research. 2007. Vol.18: 425-452.

[18] Henri, J. F. Management Control Systems and Strategy: A Resource-Based Perspective. Accounting, Organizations and Society. 2005. Vol.31(6): 529-558. 
[19] Widener, S. K. An Empirical Analysis of The Levers of Control Framework. Accounting, Organizations and Society. 2007. Vol.32: 757-788.

[20] Peljhan, D. The Role of Management Control Systems in Strategy Implementation: The Case of A Slovenian Company. Economic and Business Review. 2007. Vol.9(3): 257-280.

[21] Peljhan. Impact of Management Control System-Strategy Interaction on Performance Management: A Case Study. Journal of Management Information Systems and Human Resources. 2008. Vol.41: 174-184.

[22] Ho, J . L, H, C. J \& Wuc, A. The Impact of Management Control Systems on Efficiency and Quality Performance -An Empirical Study of Taiwanese Correctional Institutions. Asia-Pacific Journal of Accounting \& Economics. 2011. Vol.18: 77-94.

[23] Berry, A. J, Coad, A.F, Harris, E.P, Otley, D.T \& Stringer, C. Emerging Themes in Management Control: A Review of Recent Literature. The British Accounting Review. 2009. Vol.4(1): 2-20.

[24] Agbejule, A. Organizational Culture and Perfomance: The Role of Management Accounting System. Journal of Applied Accounting Research. 2011. Vol.12(1): 74-89.

[25] Yusnaini. Agency Theory dan Management Control Systems dalam Konteks Budaya Asia. Jurnal Ekonomi dan Informasi Akuntansi (Jenius). 2011. Vol.1(1): 37-45.

[26] Ojera, P. B, Ogutu, M, Siringi, E. M and Othuon, L. A. Belief Control Practices and Organizational Performances: A Survey of Sugar Industry in Kenya. An International Multidisciplinary Journal. 2011. Vol. 5(4): 1-17.

[27] Ashina, K. Management Control Systems and Performace: Essay of Modelling. Journal of Business and Management Review. 2012. Vol.1(9): 95-105.

[28] Arachchilage, N. D. K and Smith, M. The Effects of the Diagnostic and Interactive Use of Management Control Systems on the Strategy-Performance Relationship. Journal of Applied Management Accounting Research. 2013. Vol.11(1): 9-27.

[29] Ismail, T, Wiyantoro, L. S, Meutia and Muchlisha, M. Strategy, Interactive Control System and National Culture: A Case Study of Batik Industry in Indonesia. Social and Behavioral Sciences. 2012. Vol.65: 33-38.

[30] Ismail, T. Feed Forward Control System, Organizational Learning and Business Unit Performance International Journal of Social Science and Humanity. 2013. Vol.3(4): 349-353.

[31] Ismail. Formatting Strategy and Management Control System: Evidence from Indonesia. International Journal of Business and Social Science. 2013.Vol.4(1): 196-205.

[32] Ismail. Interactive Control System dan Strategi untuk Meningkatkan Pembelajaran Internal Studi Kasus pada Industri Kreatif di Jawa Barat. Jurnal Organisasi dan Manajemen. 2014. Vol.10(1): 1-14.

[33] Ismail, T \& Bangun, N. Hubungan Strategi dan Kinerja dengan Penggunaan Sistem Pengendalian sebagai Variabel Moderating. Jurnal Akuntansi. 2015. Vol.19(1): 129-143.

[34] Reginato,L \& Guerriero, R..Relationships Between Enviroment, Culture, and Management Control Systems. Internasional Journal of Organizational Analysis. 2013. Vol.21(2): 219-240.

[35] Sael, V,C \& Andono, F, A..Pemberdayaan Sistem Pengendalian Manajemen dalam Rangka Meningkatkan Kinerja Pada PT.FIVA MEDIKA FARMA. Jurnal Ilmiah Mahasiswa Universitas Surabaya. 2013. Vol.2(1): 1-15.

[36] Lee, M. T \& Widener, S. Culture and Management Control Syatems in Today's High-Performing Firm. Management Accounting Quarterly. 2013. Vol.14(2): 11-18.

[37] Kariyawasam. A. H. N. Kevin, L T. and Senaratne. Impact of Management Control Systems on Return on Asset of Manufacturing Companies in Srilangka. Journal of Arts and Commerce. 2014. Vol.3(3): 1-9.

[38] Mohamed, R, Hui,W.S, Rahman, I.K.A and Aziz, R.A. The Relationship between Strategic Performance Measurement System and Organisational Capabilities:The Role of Beliefs and Boundary Control Systems. Asian Journal of Business and Accounting. 2014. Vol.7(1): 107-142.

[39] Eldridge, S, Iwaarden, J.V, Van der Wiele,T and Williams, R. Management Control Systems for Business Processes in Uncertain Environments. International Journal of Quality \& Reliability Management. 2014. Vol.31(1):66-81.

[40] Utary, A R..The Relationship Between Management Control Systems and Corporate Financial Performance (A Moderated Regression Analysis Approach from Mining Companies in Indonesia). Journal of Economics, Business, and Accountancy Ventura . 2014. Vol.17(1): 69 -80.

[41] Nisiyama, E.K, Oyadomari, J.C.T, Tsang,C.Y and De Aguiar,A.B. The Use of Management Control Systems and Operations Management Techniques. Brazilian Business Review. 2016. Vol.13(2): 56-81.

[42] Simon. How New Top Managers Use Control Systems as Levers's of Strategic. Strategic Management Journal. 1994. Vol.15: 169-189.

[43] Govindarajan and Fisher.Strategy, Control Systems and Resource Sharing: Effect on Business-Unit Performance. Academy of Management Journal. 1990. Vol.33(2): 259-285.

[44] Simon. Strategic Orientation and Top Management Attention to Control. Strategic Management Journal. 1991. Vol.12: 49-62.

APTIKOM J. CSIT Vol. 4, No. 3, 2019: 96-104 